УДК 811. 411. 21’ 243

\title{
ИСПОЛЬЗОВАНИЕ ВИДЕОМАТЕРИАЛОВ НА ЗАНЯТИЯХ ПО ДАКТИЛОЛОГИИ И РУССКОМУ ЖЕСТОВОМУ ЯЗЫКУ
}

\author{
Файзуллина Э.Ф., Ильичева Т.Е.
}

В связи с принятием в 2012 году закона о статусе жестового языка к глухим людям и их языку проявили интерес те, кто сталкивается в своей работе с глухими гражданами. Сотрудников полищии, органов сочиальной защиты, медищинских работников и т.п. стали обучать жестовому языку на различных курсах. Однако возникло большое количество вопросов: чему обучать, как обучать, как перевести на жестовый язык многочисленные профессиональные термины? В статье рассматриваются возможности использования видеоматериалов как визуальной формы представления информации с иелью повышения восприятия материала на курсах по обучению русскому жестовому языку сотрудников органов внутренних дел.

Ключевые слова: жестовый язык; сурдокоммуникация; учебные программы; видеоматериаль.

\section{USE OF VIDEO MATERIALS IN LESSONS IN DACTYLOLOGY AND RUSSIAN HARD LANGUAGE}

Fayzullina E.F., Ilyicheva T.E.

In connection with the adoption in 2012 of a law on the status of sign language for deaf people and their language, those who are faced with deaf citizens in their work have shown interest. Police officers, social protection authorities, medical workers, etc. began to teach sign language at various courses. However, a large number of questions arose: what to teach, how to teach, how to translate numerous professional terms into sign language? The article discusses the possibilities of using 
video materials as a visual form of presenting information in order to increase the perception of material in courses on teaching Russian sign language to employees of internal affairs bodies.

Keywords: sign language; sign communication; training programs; video materials.

\section{Введение}

Все мы в большей или меньшей степени умеем/можем выражать свои эмоции с помощью жестов. При этом жесты выступают помощниками, а не основными элементами нашего общения: соглашаясь, мы киваем головой, при отказе - крутим ею из стороны в сторону. Мы улыбаемся, когда видим, как дети изображают руками сильного человека, активно используя в своей речи жесты, но не понимаем, злимся и раздражаемся, когда глухие люди разговаривают на улице, когда от группы, занимающей почти всю улицу, слышим непонятные нам возгласы, звуки, крики. Нам кажется это диким, мы считаем это невоспитанностью и совершенно не интересуемся «миром глухих».

\section{Материалы и методы}

Методический инструментарий исследования включает в себя такие методы, как обобщение и моделирование, позволившие сформулировать основные выводы. В качестве материалов исследования использованы также статистические данные, учебные программы, словари жестового языка.

\section{Результаты исследования}

В 2012 году в Российской Федерации ратифицирована Конвенция о правах инвалидов (далее - Конвенция), которая обосновала необходимость создания более комфортных условий в обществе для людей с ограниченными возможностями здоровья. Цель данной Конвенции заключается в защите и обеспечении полного и равного осуществления инвалидами всех прав человека и основных свобод. Государства, подписавшие и ратифицировавшие Конвенцию, должны предпринимать все надлежащие меры для поддержки жестовых 
языков и других альтернативных способов общения по выбору инвалидов, признавать и поощрять их использование, содействовать освоению жестового языка.

В декабре 2012 года принят Закон о статусе жестового языка, и постепенно проявился интерес к глухим людям и их языку со стороны общества, органов соцзащиты и полиции, в основном тех, кто сталкивается в своей работе с глухими гражданами. И те, и другие хотят помочь, но не могут объясниться с глухим. В этом случае на помощь приходят курсы по изучению жестового языка.

Для реализации положений Конвенции Министерство внутренних дел Российской Федерации разработало ряд нормативных правовых актов, регулирующих обучение языку жестов сотрудников полиции. Так, 1 января 2016 года вступили в силу сразу два приказа МВД России о владении сотрудниками органов внутренних дел навыками русского жестового языка:

- приказ МВД России от 12.05.2015 № 544 «Об утверждении Порядка определения должностей в органах внутренних дел Российской Федерации, исполнение обязанностей по которым требует владения сотрудниками органов внутренних дел Российской Федерации навыками русского жестового языка». Данный документ определяет должности в подразделениях органов внутренних дел Российской Федерации, исполнение обязанностей по которым требует от сотрудника полиции навыков владения русским жестовым языком;

- приказ МВД России и Минобрнауки Российской Федерации от 15.06.2015 № 681/587 «Об объеме владения навыками русского жестового языка сотрудниками органов внутренних дел Российской Федерации, замещающими отдельные должности в органах внутренних дел Российской Федерации», который устанавливает следующий объем владения навыками русского жестового языка сотрудниками полиции:

- знание общих основ теории перевода;

- знание русского жестового языка как лингвистической системы; 
- осуществление прямого перевода устной речи (синхронного, последовательного) для лиц с нарушением слуха либо обратного перевода (синхронного, последовательного) для слышащих граждан;

- обеспечение соответствия перевода устной речи на русский жестовый язык по смысловому содержанию;

- соблюдение установленных терминов и определений в области права при осуществлении перевода.

- приказ МВД России от 22.06.2017 № 405 «О внесении изменений в Порядок определения должностей в органах внутренних дел Российской Федерации, исполнение обязанностей по которым требует владения сотрудниками органов внутренних дел Российской Федерации навыками русского жестового языка, утвержденный приказом МВД России от 12.05.2015 № 544».

Из этого следует, что навыкам русского жестового языка обучаются сотрудники подразделений дежурных частей, участковых уполномоченных полиции, патрульно-постовой службы, по обеспечению безопасности дорожного движения, уголовного розыска, по вопросам миграции. Целью обучения является последовательное совершенствование профессиональных знаний, умений и навыков посредством формирования у сотрудников полиции комплекса теоретических знаний о дактилологии, жестовом языке, об особенностях общения с инвалидами по слуху, а также развитие умений и навыков выстраивать с ними диалогическое общение при помощи дактильной речи и жестового языка. В связи с этим возникли насущные вопросы: Как учить? Чему учить? Кто должен учить?

К сожалению, русский жестовый язык мало изучен. В свое время Г. Л. Зайцева ввела понятия РЖЯ и КЖЯ (русский жестовый язык и калькирующая жестовая речь). РЖЯ - это основное средство межличностной коммуникации большинства глухих и ряда слабослышащих людей. В КЖЯ жесты идут в той же последовательности, что и словесная речь («Краткий очерк по лингвистике русского жестового языка». Т. Давиденко, А. Комарова). Понятно, что КЖЯ изучить легче. Кажется, что можно, не задумываясь, переводить слова на жесты и тебя точно поймут! К сожалению, это далеко не 
так. Во-первых, если выполнять «прямой» перевод, то мы не передадим мысль правильно, т.к. в русском языке большое количество слов являются многозначными, а значит, осуществлять перевод необходимо с учетом этих значений либо коммуникативной ситуации в целом. Во-вторых, необходимо иметь достаточно большой запас жестов. Как этого достичь за небольшое количество аудиторных часа, отведенных на изучение «Основ русского жестового языка»? Конечно, можно выучить дактиль и проговорить глухому человеку фразы при помощи него. Однако сами глухие очень плохо воспринимают дактильную речь и редко используют её при разговоре. А главное - через две-три минуты активного дактилирования устают обе стороны: у одного устает рука, другой перестаёт воспринимать информацию. Вывод один - нужно изучать РЖЯ. А это такой же иностранный язык, как и английский, немецкий китайский. Язык, имеющий свою грамматику, полностью отличающуюся от грамматики словесного языка, язык вариативный, с немануальным компонетом и многозначностью.

Сотрудники органов внутренних дел, согласно основной образовательной программе, должны изучить дактильную азбуку и 75100 жестов. А целью изучения предмета является воспроизведение и владение основными элементарными моделями жестового общения, умение установить контакт с людьми, имеющими нарушение функции слуха, приобретение навыков коммуникации посредством жестового языка.

Как известно, сформировать умения и навыки общения на любом иностранном языке достаточно быстро возможно, находясь в конкретной языковой среде. То же самое происходит и при изучении русского жестового языка. К сожалению, обеспечить возможность общения курсантов и слушателей с людьми с инвалидностью по слуху - задача не всегда выполнимая. Надо отдать должное, глухие откликаются на просьбы преподавателей и с удовольствием приходят на занятия, однако и здесь встречаются свои особенности: языковой барьер в общении с глухими затрудняет взаимодействие глухих и слушателей в течение практического занятия. Приглашать же на каждое занятие сурдопереводчика не представляется возможным. 
Выход из сложившейся ситуации - использование видеороликов на жестовом языке, рассчитанных на изучение базовых ситуаций профессионального общения: установление личности подозреваемого, нарушение правил дорожного движения, неправомерное поведение в общественных местах, оказание помощи пострадавшему. В подготовке сценария принимали участие лица с нарушением слуха, переводчик жестового языка, сотрудники полиции, владеющие РЖЯ. Благодаря им многие профессиональные термины были переведены на жестовый язык в нескольких вариантах, отобраны некоторые визуальные жесты, активно использующиеся сегодня глухими.

Визуальная форма представления информации повышает восприятие материала. Если при изучении иностранных языков большую роль играет аудиоформа учебных фильмов, то использование видеофильмов на жестовом языке позволяет обратить внимание не только на конкретные жесты, но и на мимику и пантомиму при жестовой речи, выявить артикуляционные особенности участников видеоролика, чему способствует возможность замедления видеоряда. Именно замедленный показ конкретного предложения с параллельным переводом на словесный язык помогает курсантам и слушателям соотнести грамматические конструкции, используемые в РЖЯ, со звучащей на словесном языке речью, сопоставить предлагаемые варианты тех или иных жестов с изученными, рассмотреть мимику глухого, ведь, как известно, немануальный компонент позволяет зачастую отличить один жест от другого. Использование видео в процесс обучения способствует не только выработке навыков жестовой речи, но и концентрирует внимание, развивает память. Совместная познавательная деятельность при просмотре видеоролика, перевод тех или иных предложений на жестовый язык, поиск особенностей строения предложений на жестовом языке в конечном итоге дает положительный результат.

\section{Заключение}

Создание и использование видеоматериалов для изучения русского жестового языка способствует удовлетворению основных коммуникативных потребностей обучающихся в реальных ситуациях 
общения с носителями жестового языка в бытовой и социальнокультурной сферах. Языковой материал в видеороликах отобран с целью увеличения количества жестов и развития разноструктурности речи с учётом функционировании русского жестового языка как в бытовой сфере общения, так и в профессиональной деятельности сотрудника органов внутренних дел. Видеоматериалы направлены на усвоение знаний об устройстве русского жестового языка, об особенностях его употребления в разных условиях общения, на воспитание культуры общения с людьми с нарушениями функции слуха.

\section{Список литературы}

1. Зайцева Г.Л., Фрумкина Р.М. Психолингвистические аспекты изучения жестового языка // Дефектология. 1981. №1.

2. Комарова А.А., Чаушьян Н.А. Лингвистические права глухих. М.: ОООИ ВОГ, 2008. С. 122-129.

3. Русский жестовый язык: Первая лингвистическая конференция. Сборник статей / Под ред. О.В. Фёдоровой. М., 2012. 144 стр.

4. Теория и практика русского жестового языка: учебное пособие / В.В. Посиделова, С.Э. Валдавина, Е.Ю. Хорошко, Л.В. Науразбаева, Ю.В. Довгалева, В.С. Рукавишникова. (Гриф МВД России). М.: ДГСК МВД России, 2018.

\section{References}

1. Zajceva G.L., Frumkina R.M. Psiholingvisticheskie aspekty izuchenija zhestovogo jazyka [Psycholinguistic aspects of the study of sign language]. Defektologija [Defectology]. 1981. №1.

2. Komarova A.A., Chaush'jan N.A. Lingvisticheskie prava gluhih [Linguistic rights of the deaf]. M.: OOOI VOG, 2008. P. 122-129.

3. Russkij zhestovyj jazyk: Pervaja lingvisticheskaja konferencija. Sbornik statej [Russian sign language: The first linguistic conference. Collection of articles] / ed. O.V. Fjodorova. M., 2012. 144 p.

4. Posidelova V.V., Valdavina S.Je., Horoshko E.Ju., Naurazbaeva L.V., Dovgaleva Ju.V., Rukavishnikova V.S. Teorija i praktika russkogo zhestovogo jazyka [Theory and practice of Russian sign language]. M.: DGSK MVD Rossii, 2018. 


\section{ДАННЫЕ ОБ АВТОРАХ}

Файзуллина Эльмира Фоатовна, доцент кафедры языковедения и иностранных языков КЮИ МВД России, кандидат филологических наук, доцент

Казанский юридический институт Министерства внутренних дел России

Оренбургский тракт, 128, г. Казань, 420059, Российская Федеращия

efkf@mail.ru

Ильичева Татьяна Евгеньевна, старший преподаватель кафедры языковедения и иностранных языков КЮИ МВД России, переводчик русского жестового языка высшей категории Казанский юридический институт Министерства внутренних дел России

Оренбургский тракт, 128, г. Казань, 420059, Российская Федерачия

itae@rambler.ru

\section{DATA ABOUT THE AUTHORS}

Fayzullina EImira Foatovna, Associate Professor of the Department of Linguistics and Foreign Languages, KUI of the Ministry of Internal Affairs of Russia, Ph.D.

Kazan Law Institute of the Ministry of Internal Affairs of Russia 128, Orenburgsky tract, Kazan, 420059, Russian Federation efkf@mail.ru

Ilyicheva Tatyana Evgenievna, Senior Lecturer, Department of Linguistics and Foreign Languages, KUI of the Ministry of Internal Affairs of Russia, translator of Russian sign language highest category

Kazan Law Institute of the Ministry of Internal Affairs of Russia 128, Orenburgsky tract, Kazan, 420059, Russian Federation itae@rambler.ru 